\title{
Microvascular dysfunction: An emerging pathway in the pathogenesis of obesity-related insulin resistance.
}

Citation for published version (APA):

Muris, D. M. J., Houben, A. J., Schram, M. T., \& Stehouwer, C. D. A. (2013). Microvascular dysfunction: An emerging pathway in the pathogenesis of obesity-related insulin resistance. Reviews in Endocrine \& Metabolic Disorders, 14(1), 29-38. https://doi.org/10.1007/s11154-012-9231-7

Document status and date:

Published: 01/03/2013

DOI:

10.1007/s11154-012-9231-7

Document Version:

Publisher's PDF, also known as Version of record

Document license:

Taverne

Please check the document version of this publication:

- A submitted manuscript is the version of the article upon submission and before peer-review. There can be important differences between the submitted version and the official published version of record.

People interested in the research are advised to contact the author for the final version of the publication, or visit the DOI to the publisher's website.

- The final author version and the galley proof are versions of the publication after peer review.

- The final published version features the final layout of the paper including the volume, issue and page numbers.

Link to publication

\footnotetext{
General rights rights.

- You may freely distribute the URL identifying the publication in the public portal. please follow below link for the End User Agreement:

www.umlib.nl/taverne-license

Take down policy

If you believe that this document breaches copyright please contact us at:

repository@maastrichtuniversity.nl

providing details and we will investigate your claim.
}

Copyright and moral rights for the publications made accessible in the public portal are retained by the authors and/or other copyright owners and it is a condition of accessing publications that users recognise and abide by the legal requirements associated with these

- Users may download and print one copy of any publication from the public portal for the purpose of private study or research.

- You may not further distribute the material or use it for any profit-making activity or commercial gain

If the publication is distributed under the terms of Article $25 \mathrm{fa}$ of the Dutch Copyright Act, indicated by the "Taverne" license above, 


\title{
Microvascular dysfunction: An emerging pathway in the pathogenesis of obesity-related insulin resistance
}

\author{
Dennis M. J. Muris • Alfons J. H. M. Houben • \\ Miranda T. Schram • Coen D. A. Stehouwer
}

Published online: 9 January 2013

(C) Springer Science+Business Media New York 2013

\begin{abstract}
The prevalence of type 2 diabetes mellitus (T2DM) and its major risk factor, obesity, has reached epidemic proportions in Western society. How obesity leads to insulin resistance and subsequent T2DM is incompletely understood. It has been established that insulin can redirect blood flow in skeletal muscle from non-nutritive to nutritive capillary networks, without increasing total blood flow. This results in a net increase of the overall number of perfused nutritive capillary networks and thereby increases insulin-mediated glucose uptake by skeletal muscle. This process, referred to as functional (nutritive) capillary recruitment, has been shown to be endothelium-dependent and to require activation of the phosphatidylinositol-kinase (PI3K) pathway in the endothelial cell. Several studies have demonstrated that these processes are impaired in states of microvascular dysfunction. In obesity, changes in several adipokines are likely candidates to influence insulin signaling pathways in endothelial cells, thereby causing microvascular dysfunction. Microvascular dysfunction, in turn, impairs the timely access of glucose and insulin to their target tissues, and may therefore be an additional cause of insulin resistance. Thus, microvascular dysfunction may be a key feature in the development of obesity-related insulin resistance. In the present review, we will discuss the evidence for this
\end{abstract}

\footnotetext{
D. M. J. Muris · A. J. H. M. Houben · M. T. Schram •

C. D. A. Stehouwer $(\square)$

Department of Internal Medicine, Maastricht University Medical Centre (MUMC+), P.O. Box 5800, 6202 AZ Maastricht, the Netherlands

e-mail: cda.stehouwer@mumc.nl

D. M. J. Muris • A. J. H. M. Houben • M. T. Schram •

C. D. A. Stehouwer

Cardiovascular Research Institute Maastricht (CARIM),

Maastricht University, Maastricht, the Netherlands
}

emerging role for the microcirculation as a possible link between obesity and insulin resistance.

Keywords Microcirculation - Type 2 diabetes mellitus . Insulin resistance $\cdot$ Endothelial dysfunction

\section{Introduction}

The prevalence of obesity is increasing worldwide and has reached epidemic proportions in Western society [1]. Central obesity and a sedentary lifestyle are main causes of insulin resistance and type 2 diabetes mellitus (T2DM) [2, 3]. The increases in their prevalence results in an increased prevalence of T2DM, with an estimated 285 million people with T2DM worldwide and a further seven million people developing T2DM each year [4]. However, how obesity leads to T2DM is incompletely understood, and further insight into this pathophysiology may contribute to more precise risk assessment for the development of T2DM and additionally to new treatment targets for prevention of T2DM.

Microvascular dysfunction may be both cause and consequence of T2DM. On the one hand, it is generally accepted that T2DM causes microvascular dysfunction and microvascular complications such as nephropathy and retinopathy [5]. On the other hand, microvascular dysfunction has been identified as an antecedent of T2DM [5]. In addition, we [6-8] and others [9, 10] have demonstrated that microvascular dysfunction is impaired in (central) obesity, and obesity has been suggested as a primary cause of microvascular dysfunction [11]. Therefore, microvascular dysfunction may be an intermediate step linking central obesity to insulin resistance and T2DM [11-14].

In the present review, we will discuss the role of microvascular dysfunction as a key feature in the development of obesity-related insulin resistance and T2DM. 


\section{Microcirculation: definition, function, and assessment}

The microcirculation can be defined anatomically, i.e. as vessels less than $150 \mu \mathrm{m}$ in diameter, including all capillaries and venules and small arterioles [15]. However, this definition excludes larger arterioles with a diameter above $150 \mu \mathrm{m}$, which may be important to microcirculatory function [15]. An alternative definition is based on arterial/arteriolar vessel physiology, and includes all vessels that respond to increased pressure by a myogenic reduction in lumen diameter. Such a definition also includes the larger arterioles in the microcirculation in addition to capillaries and venules $[11,15,16]$.

The microcirculation has three essential functions which serve to regulate whole body and tissue metabolism, and blood pressure $[12,13]$ : 1) regulation of the exchange of nutrients, oxygen, and hormones; 2) avoidance of large fluctuations in hydrostatic pressure at the capillary level; and 3) determining the overall peripheral resistance, since the quantitatively most substantial drop in hydrostatic pressure occurs at the level of the microcirculation [15]. Microvascular dysfunction is defined as an impairment in one or more of these functions.

Currently, several types of estimates of microvascular (endothelial or smooth muscle cell) function are available [17]. First, assessment of microvascular function in specific microvascular beds is frequently used, such as in 1) skin (by capillaroscopy and laser-Doppler fluxmetry); 2) muscle (by plethysmography and contrast-enhanced ultrasonography); 3) conjunctival bed (by intravital microscopy) and 4) retina (by photography). Responses can be studied in the basal state and after applying a stimulus, such as reactive hyperemia, heating, or local or systemic administration of endothelium-(in)dependent vasoactive agents such acetylcholine and sodium nitroprusside, with lower responses in general reflecting microvascular dysfunction [18-20]. In addition, in the retinal microvasculature (as evaluated by retinal photography) [21-24] venular dilation and arteriolar narrowing have been associated with, and may be markers of, endothelial dysfunction [25]. Moreover, responses of the retinal microvasculature can be studied after applying a flicker-light stimulus, with lower responses thought to reflect endothelial dysfunction [26]. Second, microvascular function can be assessed with the use of biomarkers. Thus, measurement of plasma levels of endothelium-derived regulatory proteins (e.g. soluble E-selectin (sE-selectin), soluble intercellular adhesion molecule 1 (sICAM-1), soluble vascular adhesion molecule 1 (sVCAM-1), and von Willebrand factor (vWF) [27]) is often used. Increased levels of these markers are thought to reflect endothelial permeability to leucocytes (i.e. sE-selectin, sICAM-1, and sVCAM-1) [27-30], and prothrombotic and procoagulant activity (i.e. vWF) $[27,29,30]$. Note that the microvascular endothelium is the most important determinant of these plasma markers of endothelial dysfunction [27, 31-33], because of its large surface area and production capacity (i.e. the microvasculature covers $98 \%$ of the total vascular surface area [34]). For these reasons, it is plausible to assume that higher circulating concentrations of these markers reflect microvascular endothelial dysfunction. Another biomarker of microvascular function is urinary albumin excretion or microalbuminuria, which is thought to reflect a generalized increase in endothelial permeability [27], and is frequently used as a marker of general endothelial dysfunction [27, 29, 30, 35-37]. This concept is derived from data showing that microalbuminuria is associated with a greater transcapillary escape rate of albumin, i.e. with greater microvascular permeability [27] and from data showing that microalbuminuria is strongly associated with risk of cardiovascular disease, that this association cannot be explained by conventional risk factors, and that changes in microalbuminuria are paralleled by changes in cardiovascular risk (reviewed elsewhere [38]). In general, assessment of microvascular function in specific vascular beds is technically demanding and time-consuming, and is thus mostly used in relatively small-scale, experimental studies, whereas the use of biomarkers is especially suitable for large-scale observational studies.

\section{Microvascular dysfunction: a cause of insulin resistance}

Insulin resistance is typically defined as decreased sensitivity and/or responsiveness to the metabolic actions of insulin, which results in impaired glucose disposal [11, 13, 39, 40]. In muscle cells, activation of the phosphatidylinositolkinase (PI3K) pathway leads to translocation of glucose transporter-4 (GLUT-4) to the cell membrane, which activates the downstream pathways of glucose metabolism [11, 13, 39-41]. The translocation of GLUT-4 is believed to be the rate-limiting step for insulin-mediated glucose uptake in muscle $[41,42]$. Several studies demonstrated that inappropriate fat accumulation in muscle cells or the release of inflammatory cytokines by fat cells may affect this pathway $[41,43,44]$. This process is referred to as metabolic insulin resistance, and is widely accepted to precede the development of T2DM [45]. Nevertheless, most studies investigating metabolic insulin resistance examined individuals with long-standing T2DM [46]. These studies demonstrated that there are indeed defects in the insulin-signaling pathway in muscle cells in the diabetic state [18, 47]. However, an important and necessary step preceding translocation of GLUT-4 is the perfusion of the microvasculature within the skeletal muscle in order to deliver insulin and glucose to the muscle cells. 
Since the 1990s, there has been an increasing interest in this precellular step, and it has become clear that the delivery of insulin and glucose to muscle tissue is regulated by insulin itself via direct effects on microvascular function that require activation of the insulin receptor on endothelial cells $[11,40]$. Baron and colleagues [48] first reported that insulin increases total blood flow in skeletal muscle, which is paralleled by an increase in insulin-mediated glucose uptake $[48,49]$. Although some studies have confirmed this vascular action of insulin [50,51], most studies observed only insulin-mediated increases in total limb blood flow after using supra-physiological doses of insulin or after several hours of delay when physiological concentrations were used [52-54]. Therefore, the physiological importance of insulin's ability to increase total blood flow remains controversial [11, 18, 53]. However, besides these actions on resistance vessels, insulin can redirect blood flow in skeletal muscle from non-nutritive to nutritive capillary networks, without increasing total blood flow. This results in a net increase of the overall number of perfused nutritive capillary networks [11], and thereby increases insulin-mediated glucose uptake by skeletal muscle $[40,52]$. This process is referred to as functional (nutritive) capillary recruitment. Such capillary recruitment requires physiological concentrations of insulin and has a time course that accords well with the time course for insulin-mediated glucose uptake in skeletal muscle [39, 53, 55]. In addition, this process has been shown to be endothelium-dependent, requiring activation of the PI3K pathway in the endothelial cell [39], including the insulin receptor, insulin receptor substrate 1 (IRS-1), insulin receptor substrate 2 (IRS-2) [56], phosphoinositide-dependent kinase 1 (PDK-1), and protein kinase B (Akt) [39, 41] (Fig. 1). In contrast to muscle cells, this activation does not result in translocation of GLUT-4 to the cell surface, but in the production of NO due to increased endothelial NO synthase (eNOS) activity [39] (Fig. 1). Consequently, insulin-induced stimulation of endothelial cells leads to increased NO production, which stimulates capillary recruitment [39] and transendothelial transport of insulin [57]. In addition, however, insulin also has vasoconstrictor effects through the production of endothelin-1 (ET-1) through stimulation of the intracellular MAP kinase signaling (MAPK) pathway and extracellular signal-regulated kinase-1/2 (ERK-1/2) (Fig. 1) [39]. In physiological conditions, when insulin binds to the insulin or insulin-like growth factor receptor on endothelial cells [58], the net result usually favors NO production [11] and thus vasodilatation and capillary recruitment.

There now is substantial evidence, derived from both animal experiments and observations in humans, that this pathway is an important determinant of insulin-mediated glucose uptake in muscle. Thus, Clark and colleagues [59] were the first to report insulin-mediated capillary recruitment in skeletal

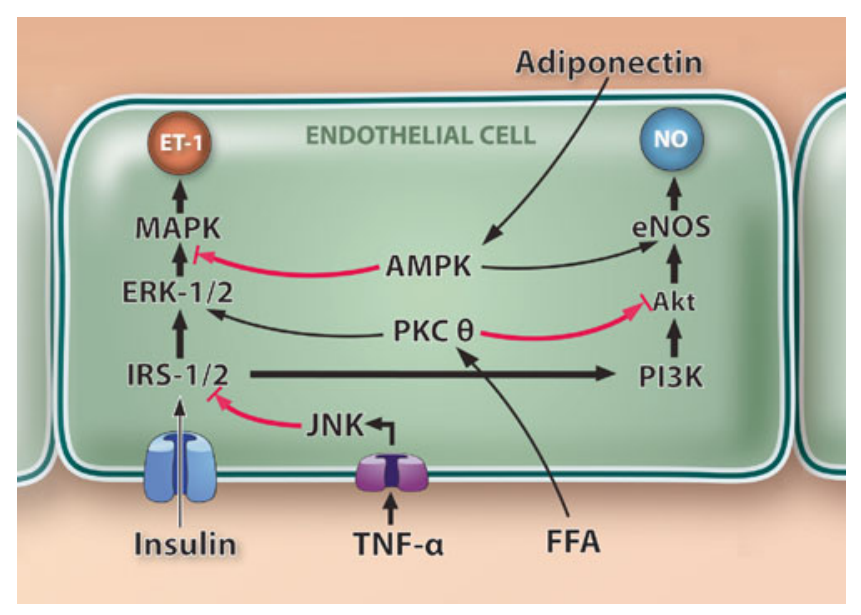

Fig. 1 When insulin binds on the insulin receptor of endothelial cells, the PI3K and MAPK pathways in the endothelial cell are activated. These activations lead to the production of NO and ET-1, resulting in vasodilatation and vasoconstriction respectively. Normally, the net result usually favors NO production, resulting in a redirection of blood flow in skeletal muscle from non-nutritive capillaries to nutritive capillaries, thereby increasing insulin-mediated glucose uptake by skeletal muscle. In obesity, there is an increase in several circulating adipose tissue-derived factors, in particular FFA and TNF- $\alpha$, whereas the anti-inflammatory adipokine adiponectin is decreased. FFA and TNF- $\alpha$ affect the insulin signaling pathway in endothelial cells by the activation of PKC $\theta$ and JNK respectively. In addition, decreased adiponectin levels decrease AMPK phosphorylation. Accordingly, these endocrine factors are likely candidates to influence insulin signaling pathways (i.e. decreased PI3K activation and increased ERK-1/ 2 activation) in endothelial cells, thereby impairing insulin-mediated vasodilatation and capillary recruitment, and thus skeletal muscle glucose uptake. black arrows - stimulation; red arrows - inhibition; IRS$1 / 2$ - insulin receptor substrate $1 / 2$; PI3K - phosphatidylinositol-kinase-dependent; Akt - protein kinase B; eNOS — endothelial nitric oxide synthase; NO - nitric oxide; ERK-1/2 - extracellular signalregulated kinase-1/2; ET-1 - endothelin-1; FFA - free fatty acids; TNF- $\alpha$ - tumor necrosis factor- $\alpha$; JNK-intracellular enzyme c-Jun N-terminal kinase; PKC $\theta$-protein kinase C; AMPK—-5' adenosine monophosphate-activated protein kinase

muscle of the rat hind limb. In subsequent in vivo rat studies, the effect of insulin on capillary perfusion was confirmed [54, $60,61]$. In human muscle, it was established that insulin increased microvascular blood volume [62, 63]. In addition, hyperinsulinemia was shown to enhance skin post-occlusive capillary recruitment and microvascular vasomotion [64, 65]. Moreover, capillary recruitment and acetylcholinemediated vasodilatation of both skin and resistance arteries were strongly associated with insulin sensitivity [66-70] In further support of the physiological importance of insulin-mediated capillary recruitment, several studies have demonstrated that insulin-mediated capillary recruitment contributes to glucose disposal in skeletal muscle [6, 52, 55, 56, 63, 71, 72]. In subsequent studies, it was established that approximately $40 \%$ of insulin-mediated glucose uptake by skeletal muscle can be attributed to capillary recruitment $[55,73,74]$. In 
pathophysiological conditions, both obese Zucker rats [75] and obese insulin-resistant humans [6-8, 62, 66, $72,76-80]$ are characterized by impaired capillary recruitment as well as impaired insulin-mediated glucose uptake by skeletal muscle in the basal state and during hyperinsulinemia.

In accordance, accumulating evidence supports the hypothesis that microvascular dysfunction precedes and even predicts the development T2DM. First, a growing number of prospective studies have shown that microvascular dysfunction is associated with incident impaired fasting glucose (IFG) and incident T2DM. Recently, we analyzed and pooled thirteen [81-93] prospective population-based studies in a meta-analysis [94]. These studies focused on the microvasculature of the skin, eye, and kidney. When all estimates of microvascular dysfunction were combined, we found that, per standard deviation (SD) greater microvascular dysfunction, the incidence of IFG increased by $15 \%$ and the incidence of $\mathrm{T} 2 \mathrm{DM}$ increased by $25 \%$, in a follow-up period ranging from 2.6 to 12 years. In addition, one SD greater endothelial dysfunction, as measured with plasma levels of endothelium-derived regulatory proteins - which are likely to be derived from microvascular endothelium [95] -, was associated with a $50 \%$ higher incidence of T2DM. Second, studies which examined diet-induced insulin resistance in both vasculature and skeletal muscle demonstrated that microvascular endothelial dysfunction develops well before impaired insulin activation of PI3K in skeletal muscle [96, 97]. Third, a recent study demonstrated reduced insulin-mediated glucose uptake by skeletal muscle in tissue-specific knockout mice lacking IRS-2 in endothelial cells [56]. Importantly, glucose uptake by isolated skeletal muscle from these mice was not impaired, indicating that microvascular endothelial dysfunction causes impaired insulin-mediated glucose uptake even while insulin signaling pathways in skeletal muscle cells are intact [56].

In summary, these findings strongly support the hypothesis that microvascular dysfunction is a cause of insulin resistance, by affecting insulin-mediated glucose uptake by skeletal muscle through impaired capillary recruitment (Fig. 2) [11-14]. Subsequently, the hyperglycemia and hyperinsulinemia that evolve from metabolic insulin resistance can further impair endothelial dysfunction (and thus capillary recruitment) [98-100] and glucose disposal [18], which results in a vicious circle (Fig. 2).

Importantly, by increasing peripheral vascular resistance, microvascular dysfunction can also contribute to the development of hypertension (Fig. 2), which suggests that microvascular dysfunction constitutes one of the links between insulin resistance and hypertension in the metabolic syndrome (reviewed elsewhere [11-14]).

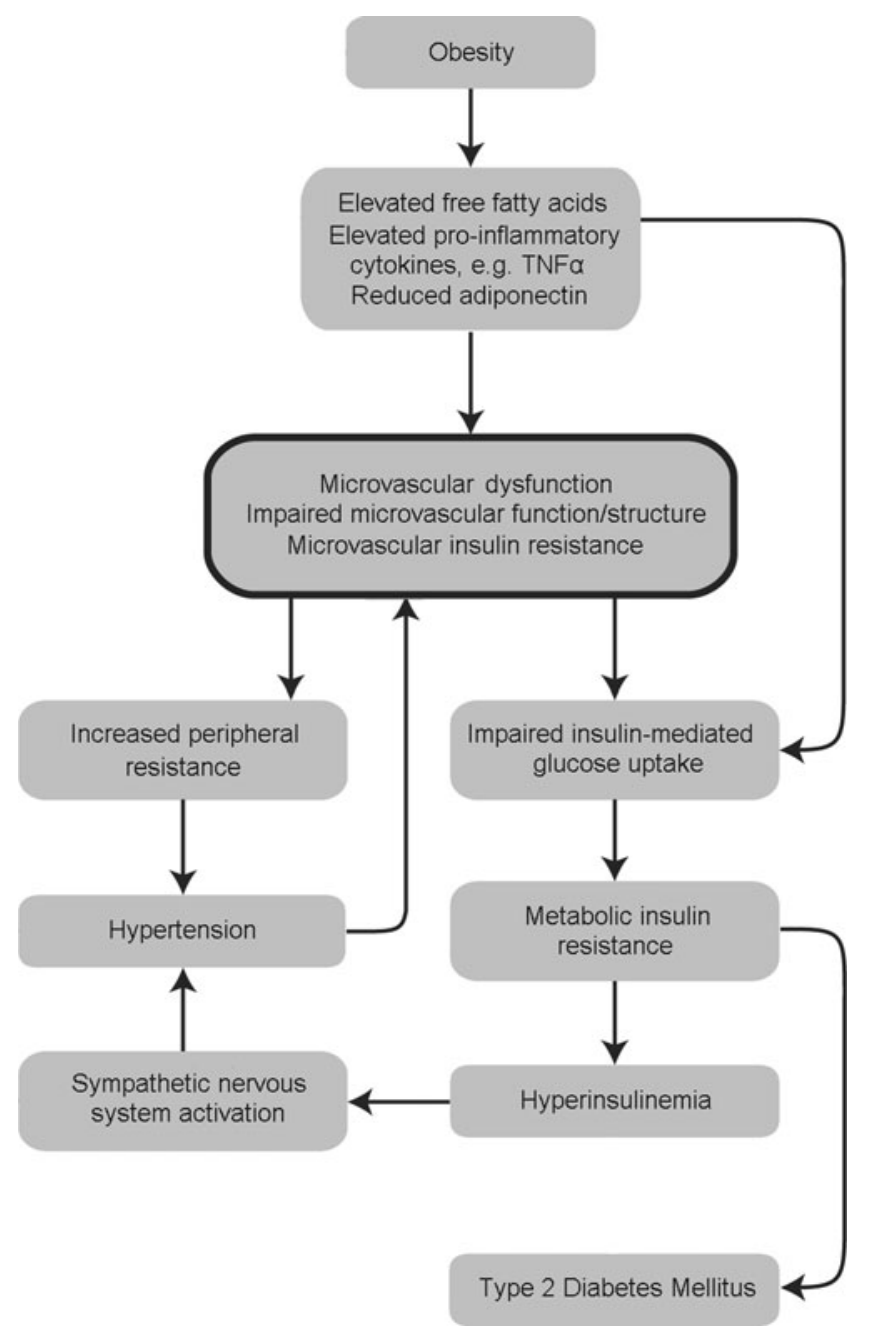

Fig. 2 Hypothesis describing microvascular dysfunction as an intermediate step linking central obesity to insulin resistance (and, downstream, T2DM) and hypertension (adapted from Jonk [18]). TNF- $\alpha-$ tumor necrosis factor- $\alpha$

\section{Obesity: a cause of microvascular dysfunction}

\subsection{Obesity-related intracellular signaling}

We $[6-8]$ and others $[9,10,62,101,102]$ have demonstrated that microvascular dysfunction is impaired in obesity and that microvascular dysfunction develops progressively along with an increase in adipose tissue [40, 67, 103]. In obesity, insulin-mediated activation of the PI3K pathway in endothelial cells is selectively impaired while the insulinmediated activation of ERK-1/2 is intact [40, 104], i.e. there is endothelial or microvascular insulin resistance with regard to insulin's vasodilator actions. For example, studies in diet-induced obesity in animals revealed blunted PI3K signaling pathways in endothelial cells through impaired insulin-mediated phosphorylation of Akt [96, 105, 106] and eNOS [56, 96, 105, 107], whereas insulin-mediated ET-1 expression was unchanged [56, 107]. 
Thus, obesity-related microvascular dysfunction is characterized by cellular defects in endothelial cells that influence the balance between vasodilatation and vasoconstriction. The selective insulin signaling impairment in endothelial cells results in decreased NO production, which reduces insulin-mediated nutritive capillary recruitment [39] and trans-endothelial transport of insulin [57]. Consequently, there is a decreased insulin-mediated glucose uptake in skeletal muscle, i.e. skeletal muscle (i.e. metabolic) insulin resistance (Fig. 2). Therefore, endothelial insulin signaling defects play an important role in the development of obesity-related insulin resistance.

\subsection{Obesity-related endocrine signaling}

The close association between adipose tissue and microvascular functioning strongly suggests signaling pathways between adipose tissue and the microcirculation [11, 40]. Adipose tissue and in particular visceral adipose tissue cells secrete a variety of bioactive substances called adipokines $[11,40]$. In obesity, there is an enhanced production of free fatty acids (FFAs), tumor necrosis factor (TNF)- $\alpha$, leptin, resistin, and several other inflammatory cytokines [11, 40], whereas the production of adiponectin, an antiinflammatory adipokine, is reduced [11, 108].

Several studies have demonstrated that systemic FFA infusion inhibits insulin-mediated capillary recruitment $[80$, 109-111] and forearm blood flow responses [112] with subsequent blunted insulin-mediated glucose uptake by skeletal muscle [109-111, 113-117]. Conversely, lowering FFA levels in obese subjects improved basal and insulin-mediated capillary recruitment in obese insulin-resistant individuals [80]. FFA may induce insulin resistance through activation of protein kinase $\mathrm{C}(\mathrm{PKC}) \theta$ which subsequently inhibits insulinmediated phosphorylation of Akt and stimulates ERK-1/2 (Fig. 1) [118].

TNF- $\alpha$ inhibits both insulin-mediated capillary recruitment and insulin-mediated glucose uptake by skeletal muscle $[103,119,120]$. TNF- $\alpha$ may induce endothelial insulin resistance trough activation of intracellular enzyme c-Jun N-terminal kinase (JNK) [121]. JNK has been shown to regulate both whole-body insulin sensitivity and insulin-mediated cell signaling [40, 122]. Hence, activation of JNK impairs the PI3K pathway and stimulates the phosphorylation of ERK-1/2 in endothelial cells $[121,123]$, resulting in insulinmediated vasoconstriction (Fig. 1) [40]. Conversely, a recent study found that specific inhibition of JNK in $d b / d b$ mice can restore the blunted insulin-mediated vasodilatation [124].

Adiponectin has been shown to increase insulin sensitivity and improve vascular function [125]. These beneficial effects are probably attributable to stimulation of $5^{\prime}$ adenosine monophosphate-activated protein kinase (AMPK) phosphorylation by adiponectin, which enhances insulin-mediated vasodilatation through increased eNOS phosphorylation and decreased ERK-1/2 stimulation (Fig. 1) [126, 127]. In addition, adiponectin itself can reduce the production of proinflammatory cytokines, which has favorable affects of insulin-signaling pathways [13, 128, 129]. In obesity, adiponectin levels are decreased, which is probably caused by TNF $\alpha$ and IL-6, as well as by other inflammatory mediators [13, 129, 130].

Another important system that has been suggested to be involved in microvascular functioning is the reninangiotensin system (RAS) [11]. All the components of the RAS necessary to generate the vasoconstrictor angiotensin II (AngII) are expressed in human adipose tissue [11, 131, 132]. In obese subjects there is enhanced activation of the RAS, which may directly relate to the mass of adipose tissue $[11,133]$. Enhanced RAS activity may have detrimental effects on insulin-mediated skeletal muscle glucose uptake by 1) affecting insulin-mediated IRS-1 phosphorylation in endothelial cells $[134,135]$; 2) production of reactive oxygen species (ROS), which reduce NO bioavailability [136, 137]; and 3) stimulation of the release of ET-1 [138, 139].

In addition to the above, leptin and other cytokines and chemokines have also been implicated in the pathogenesis of endothelial or (micro)vascular insulin resistance (reviewed elsewhere [13, 129, 140, 141]).

In summary, in obesity, there is an increase in several circulating adipose tissue-derived factors, in particular FFA and TNF- $\alpha$, whereas the anti-inflammatory adipokine, adiponectin, is decreased. These endocrine factors are likely candidates to influence insulin signaling pathways in endothelial cells, thereby causing both impaired insulin-mediated vasodilatation and impaired skeletal muscle glucose uptake (Fig. 1) [11]. Hence, these endocrine factors provide a potential link between obesityrelated microcirculatory dysfunction and obesity-related insulin resistance (Fig. 2) [11]. In addition to these systemic endocrine effects, we have postulated a vasoregulatory role for local deposits of fat next to the microvasculature (i.e. perivascular adipose tissue, PVAT) [11, 40, 142]. Adipokines released by these fat cells may directly inhibit vasodilatory pathways locally, and thus have a local rather than a systemic vasoregulatory effect, which we named "vasocrine" [11, 40, 142]. A recent animal study demonstrated dramatic increases in PVAT in muscle of $d b / d b$ mice. In addition, these mice had a reduction in adiponectin release by PVAT and decreased insulin-mediated vasodilatation [124], indicating that PVAT induces microvascular dysfunction by influencing insulin signaling and thereby insulin's microvascular effects [12]. 


\section{Conclusion}

Considerable evidence exists that microvascular dysfunction is a key feature in the development of obesity-related insulin resistance. Obesity is associated with microvascular dysfunction through alterations in endocrine and vasocrine signals that cause alterations in microvascular endothelial and skeletal muscle intracellular signaling. Microvascular dysfunction, in turn, impairs the timely access of glucose and insulin to their target tissues, and is therefore a contributor to insulin resistance.

Therefore, the microcirculation may present a target for the prevention and treatment of the metabolic syndrome and T2DM [11, 12, 40]. Hence, more studies are required for elucidation of the pathophysiological pathways that contribute to microvascular dysfunction. Unraveling this issue may contribute to more precise assessment of risk of development of the metabolic syndrome and T2DM. In addition, unraveling how microvascular dysfunction is determined and how it leads to the metabolic syndrome and T2DM may lead to new treatment targets as well as to a better understanding of why certain existing treatments (i.e. angiotensin converting enzyme- (ACE-) inhibitors, angiotensin receptor blockers (ARBs), and physical activity) are associated with decreased risk of developing the metabolic syndrome and T2DM.

\section{References}

1. Flegal KM, Carroll MD, Kit BK, Ogden CL. Prevalence of obesity and trends in the distribution of body mass index among US adults, 1999-2010. JAMA. 2012;307(5):491-7.

2. Han TS, Feskens EJ, Lean ME, Seidell JC. Associations of body composition with type 2 diabetes mellitus. Diabet Med. 1998;15 (2):129-35.

3. Manson JE, Nathan DM, Krolewski AS, Stampfer MJ, Willett WC, Hennekens $\mathrm{CH}$. A prospective study of exercise and incidence of diabetes among US male physicians. JAMA. 1992;268(1):63-7.

4. International Diabetes Federation (IDF). Diabetes atlas, 4th edition. Brussels: IDF; 2009.

5. Tooke JE, Goh KL. Vascular function in Type 2 diabetes mellitus and pre-diabetes: the case for intrinsic endotheiopathy. Diabet Med. 1999;16(9):710-5.

6. de Jongh RT, Serne EH, Ijzerman RG, de Vries G, Stehouwer CD. Impaired microvascular function in obesity: implications for obesity-associated microangiopathy, hypertension, and insulin resistance. Circulation. 2004;109(21):2529-35.

7. Jonk AM, Houben AJ, Schaper NC, de Leeuw PW, Serne EH, Smulders YM, et al. Obesity is associated with impaired endothelial function in the postprandial state. Microvasc Res. 2011;82(3):423-9.

8. Jonk AM, Houben AJ, Schaper NC, de Leeuw PW, Serne EH, Smulders YM, et al. Meal-related increases in microvascular vasomotion are impaired in obese individuals: a potential mechanism in the pathogenesis of obesity-related insulin resistance. Diabetes Care. 2011;34 Suppl 2:S342-8.

9. Agapitov AV, Correia ML, Sinkey CA, Dopp JM, Haynes WG. Impaired skeletal muscle and skin microcirculatory function in human obesity. J Hypertens. 2002;20(7):1401-5.
10. Keske MA, Clerk LH, Price WJ, Jahn LA, Barrett EJ. Obesity blunts microvascular recruitment in human forearm muscle after a mixed meal. Diabetes Care. 2009;32(9):1672-7.

11. Jonk AM, Houben AJ, de Jongh RT, Serne EH, Schaper NC, Stehouwer CD. Microvascular dysfunction in obesity: a potential mechanism in the pathogenesis of obesity-associated insulin resistance and hypertension. Physiology (Bethesda). 2007;22:252-60.

12. De Boer MP, Meijer RI, Wijnstok NJ, Jonk AM, Houben AJ, Stehouwer CD, et al. Microvascular dysfunction: a potential mechanism in the pathogenesis of obesity-associated insulin resistance and hypertension. Microcirculation. 2012;19(1):5-18.

13. Houben AJ, Eringa EC, Jonk AM, Serne EH, Smulders YM, Stehouwer CD. Perivascular fat and the microcirculation: relevance to insulin resistance, diabetes, and cardiovascular disease. Curr Cardiovasc Risk Rep. 2012;6(1):80-90.

14. Levy BI, Schiffrin EL, Mourad JJ, Agostini D, Vicaut E, Safar $\mathrm{ME}$, et al. Impaired tissue perfusion: a pathology common to hypertension, obesity, and diabetes mellitus. Circulation. 2008;118(9):968-76.

15. Levy BI, Ambrosio G, Pries AR, Struijker-Boudier HA. Microcirculation in hypertension: a new target for treatment? Circulation. 2001;104(6):735-40.

16. Verdant C, De Backer D. How monitoring of the microcirculation may help us at the bedside. Curr Opin Crit Care. 2005;11(3):240-4.

17. Knotzer H, Hasibeder WR. Microcirculatory function monitoring at the bedside-a view from the intensive care. Physiol Meas. 2007;28:R65-86.

18. Jonk AM. Microvascular actions of insulin: studies on the interaction with angiotensin II and on the postprandial state. Amsterdam: GVO drukkers \& vormgevers B.V., Ponsen \& Looijen; 2011.

19. Minson CT, Berry LT, Joyner MJ. Nitric oxide and neurally mediated regulation of skin blood flow during local heating. $\mathrm{J}$ Appl Physiol. 2001;91(4):1619-26.

20. Serne EH, Gans RO, ter Maaten JC, Tangelder GJ, Donker AJ, Stehouwer CD. Impaired skin capillary recruitment in essential hypertension is caused by both functional and structural capillary rarefaction. Hypertension. 2001;38(2):238-42.

21. Houben AJ, Stehouwer CD. Retinal microvascular abnormalities: can they predict future risk of hypertension? J Hypertens. 2009;27(12):2346-8.

22. Ikram MK, de Jong FJ, Vingerling JR, Witteman JC, Hofman A, Breteler MM, et al. Are retinal arteriolar or venular diameters associated with markers for cardiovascular disorders? The Rotterdam study. Invest Ophthalmol Vis Sci. 2004;45:2129-34.

23. Klein R, Sharrett AR, Klein BE, Chambless LE, Cooper LS, Hubbard LD, et al. Are retinal arteriolar abnormalities related to atherosclerosis?: the atherosclerosis risk in communities study. Arterioscler Thromb Vasc Biol. 2000;20:1644-50.

24. Wong TY, Islam FM, Klein R, Klein BE, Cotch MF, Castro C, et al. Retinal vascular caliber, cardiovascular risk factors, and inflammation: the multi-ethnic study of atherosclerosis (MESA). Invest Ophthalmol Vis Sci. 2006;47(6):2341-50.

25. Wilkinson-Berka JL. Vasoactive factors and diabetic retinopathy: vascular endothelial growth factor, cycoloxygenase-2 and nitric oxide. Curr Pharm Des. 2004;10:3331-48.

26. Delles C, Michelson G, Harazny J, Oehmer S, Hilgers KF, Schmieder RE. Impaired endothelial function of the retinal vasculature in hypertensive patients. Stroke. 2004;35 (6):1289-93.

27. Stehouwer CD. Is measurement of endothelial dysfunction clinically useful? Eur J Clin Invest. 1999;29(6):459-61.

28. Kubes P, Kerfoot SM. Leukocyte recruitment in the microcirculation: the rolling paradigm revisited. News Physiol Sci. 2001;16:76-80. 
29. Stehouwer CD. Endothelial dysfunction in diabetic nephropathy: state of the art and potential significance for non-diabetic renal disease. Nephrol Dial Transplant. 2004;19(4):778-81.

30. Stehouwer CD, Lambert J, Donker AJ, van Hinsbergh VW. Endothelial dysfunction and pathogenesis of diabetic angiopathy. Cardiovasc Res. 1997;34(1):55-68.

31. Kasprzak JD, Klosinska M, Drozdz J. Clinical aspects of assessment of endothelial function. Pharmacol Rep. 2006;58 (Suppl):33-40.

32. Schram MT, Stehouwer CD. Endothelial dysfunction, cellular adhesion molecules and the metabolic syndrome. Horm Metab Res. 2005;37 Suppl 1:49-55.

33. Szmitko PE, Wang CH, Weisel RD, de Almeida JR, Anderson TJ, Verma S. New markers of inflammation and endothelial cell activation: part I. Circulation. 2003;108(16):1917-23.

34. Wolinsky H. A proposal linking clearance of circulating lipoproteins to tissue metabolic activity as a basis for understanding atherogenesis. Circ Res. 1980;47:301-11.

35. Deckert T, Feldt-Rasmussen B, Borch-Johnsen K, Jensen T, Kofoed-Enevoldsen A. Albuminuria reflects widespread vascular damage. The steno hypothesis. Diabetologia. 1989;32 (4):219-26.

36. Jensen T, Bjerre-Knudsen J, Feldt-Rasmussen B, Deckert T. Features of endothelial dysfunction in early diabetic nephropathy. Lancet. 1989;1(8636):461-3.

37. Ochodnicky P, Henning RH, van Dokkum RP, de Zeeuw D. Microalbuminuria and endothelial dysfunction: emerging targets for primary prevention of end-organ damage. J Cardiovasc Pharmacol. 2006;47 Suppl 2:S151-62. discussion S172-156.

38. Stehouwer CD, Smulders YM. Microalbuminuria and risk for cardiovascular disease: analysis of potential mechanisms. J Am Soc Nephrol. 2006;17:2106-11.

39. Kim JA, Montagnani M, Koh KK, Quon MJ. Reciprocal relationships between insulin resistance and endothelial dysfunction: molecular and pathophysiological mechanisms. Circulation. 2006;113(15):1888-904.

40. Serne EH, de Jongh RT, Eringa EC, Ijzerman RG, Stehouwer CD. Microvascular dysfunction: a potential pathophysiological role in the metabolic syndrome. Hypertension. 2007;50(1):204-11.

41. Shulman GI. Cellular mechanisms of insulin resistance. J Clin Invest. 2000;106(2):171-6.

42. Shulman GI. Unraveling the cellular mechanism of insulin resistance in humans: new insights from magnetic resonance spectroscopy. Physiology (Bethesda). 2004;19:183-90.

43. Hotamisligil GS. Inflammation and metabolic disorders. Nature. 2006;444(7121):860-7.

44. Savage DB, Petersen KF, Shulman GI. Disordered lipid metabolism and the pathogenesis of insulin resistance. Physiol Rev. 2007;87(2):507-20.

45. Schalkwijk CG, Stehouwer CD. Vascular complications in diabetes mellitus: the role of endothelial dysfunction. Clin Sci (Lond). 2005;109(2):143-59.

46. Karlsson HK, Zierath JR. Insulin signaling and glucose transport in insulin resistant human skeletal muscle. Cell Biochem Biophys. 2007;48(2-3):103-13.

47. Taubes G. Insulin resistance. Prosperity's plague. Science. 2009;325(5938):256-60.

48. Laakso M, Edelman SV, Brechtel G, Baron AD. Decreased effect of insulin to stimulate skeletal muscle blood flow in obese man. A novel mechanism for insulin resistance. J Clin Invest. 1990;85 (6):1844-52.

49. Baron AD, Steinberg H, Brechtel G, Johnson A. Skeletal muscle blood flow independently modulates insulin-mediated glucose uptake. Am J Physiol. 1994;266(2 Pt 1):E248-53.

50. de Haan CH, van Dielen FM, Houben AJ, de Leeuw PW, Huvers FC, De Mey JG, et al. Peripheral blood flow and noradrenaline responsiveness: the effect of physiological hyperinsulinemia. Cardiovasc Res. 1997;34(1):192-8.

51. Tack CJ, Lutterman JA, Vervoort G, Thien T, Smits P. Activation of the sodium-potassium pump contributes to insulin-induced vasodilation in humans. Hypertension. 1996;28(3):426-32.

52. Clark MG, Wallis MG, Barrett EJ, Vincent MA, Richards SM, Clerk LH, et al. Blood flow and muscle metabolism: a focus on insulin action. Am J Physiol Endocrinol Metab. 2003;284:E241-58.

53. Yki-Jarvinen H, Utriainen T. Insulin-induced vasodilatation: physiology or pharmacology? Diabetologia. 1998;41(4):369-79.

54. Zhang L, Vincent MA, Richards SM, Clerk LH, Rattigan S, Clark $\mathrm{MG}$, et al. Insulin sensitivity of muscle capillary recruitment in vivo. Diabetes. 2004;53(2):447-53.

55. Vincent MA, Clerk LH, Lindner JR, Klibanov AL, Clark MG, Rattigan S, et al. Microvascular recruitment is an early insulin effect that regulates skeletal muscle glucose uptake in vivo. Diabetes. 2004;53(6):1418-23.

56. Kubota T, Kubota N, Kumagai H, Yamaguchi S, Kozono H, Takahashi $\mathrm{T}$, et al. Impaired insulin signaling in endothelial cells reduces insulin-induced glucose uptake by skeletal muscle. Cell Metab. 2011;13(3):294-307.

57. Wang H, Wang AX, Barrett EJ. Insulin-induced endothelial cell cortical actin filament remodeling: a requirement for transendothelial insulin transport. Mol Endocrinol. 2012;26(8):1327-38.

58. Johansson GS, Chisalita SI, Arnqvist HJ. Human microvascular endothelial cells are sensitive to IGF-I but resistant to insulin at the receptor level. Mol Cell Endocrinol. 2008;296(1-2):58-63.

59. Rattigan S, Clark MG, Barrett EJ. Hemodynamic actions of insulin in rat skeletal muscle: evidence for capillary recruitment. Diabetes. 1997;46:1381-8.

60. Clark AD, Barrett EJ, Rattigan S, Wallis MG, Clark MG. Insulin stimulates laser Doppler signal by rat muscle in vivo, consistent with nutritive flow recruitment. Clin Sci (Lond). 2001;100 (3):283-90.

61. Vincent MA, Dawson D, Clark AD, Lindner JR, Rattigan S, Clark MG, et al. Skeletal muscle microvascular recruitment by physiological hyperinsulinemia precedes increases in total blood flow. Diabetes. 2002;51(1):42-8.

62. Clerk LH, Vincent MA, Jahn LA, Liu Z, Lindner JR, Barrett EJ. Obesity blunts insulin-mediated microvascular recruitment in human forearm muscle. Diabetes. 2006;55(5):1436-42.

63. Coggins M, Lindner J, Rattigan S, Jahn L, Fasy E, Kaul S, et al. Physiologic hyperinsulinemia enhances human skeletal muscle perfusion by capillary recruitment. Diabetes. 2001;50(12):2682-90.

64. de Jongh RT, Clark AD, Ijzerman RG, Serne EH, de Vries G, Stehouwer CD. Physiological hyperinsulinaemia increases intramuscular microvascular reactive hyperaemia and vasomotion in healthy volunteers. Diabetologia. 2004;47(6):978-86.

65. Serne EH, Gans RO, ter Maaten JC, ter Wee PM, Donker AJ, Stehouwer CD. Capillary recruitment is impaired in essential hypertension and relates to insulin's metabolic and vascular actions. Cardiovasc Res. 2001;49(1):161-8.

66. Francischetti EA, Tibirica E, da Silva EG, Rodrigues E, Celoria BM, de Abreu VG. Skin capillary density and microvascular reactivity in obese subjects with and without metabolic syndrome. Microvasc Res. 2011;81(3):325-30.

67. Serne EH, Stehouwer CD, ter Maaten JC, ter Wee PM, Rauwerda JA, Donker AJ, et al. Microvascular function relates to insulin sensitivity and blood pressure in normal subjects. Circulation. 1999;99(7):896-902.

68. Grassi G, Seravalle G, Scopelliti F, Dell'Oro R, Fattori L, QuartiTrevano F, et al. Structural and functional alterations of subcutaneous small resistance arteries in severe human obesity. Obesity (Silver Spring). 2010;18(1):92-8.

69. Lampinen KH, Ronnback M, Groop PH, Kaaja RJ. A relationship between insulin sensitivity and vasodilation in women with a 
history of preeclamptic pregnancy. Hypertension. 2008;52 (2):394-401.

70. Clough GF, L'Esperance V, Turzyniecka M, Walter L, Chipperfield AJ, Gamble J, et al. Functional dilator capacity is independently associated with insulin sensitivity and age in central obesity and is not improved by high dose statin treatment. Microcirculation. 2011;18(1):74-84.

71. Vincent MA, Clerk LH, Rattigan S, Clark MG, Barrett EJ. Active role for the vasculature in the delivery of insulin to skeletal muscle. Clin Exp Pharmacol Physiol. 2005;32(4):302-7.

72. Serne EH, Ijzerman RG, Gans RO, Nijveldt R, De Vries G, Evertz R, et al. Direct evidence for insulin-induced capillary recruitment in skin of healthy subjects during physiological hyperinsulinemia. Diabetes. 2002;51(5):1515-22.

73. Newman JM, Dwyer RM, St-Pierre P, Richards SM, Clark MG, Rattigan S. Decreased microvascular vasomotion and myogenic response in rat skeletal muscle in association with acute insulin resistance. J Physiol. 2009;587(Pt 11):2579-88.

74. Vincent MA, Barrett EJ, Lindner JR, Clark MG, Rattigan S. Inhibiting NOS blocks microvascular recruitment and blunts muscle glucose uptake in response to insulin. Am J Physiol Endocrinol Metab. 2003;285:E123-9.

75. Wallis MG, Wheatley CM, Rattigan S, Barrett EJ, Clark AD, Clark MG. Insulin-mediated hemodynamic changes are impaired in muscle of Zucker obese rats. Diabetes. 2002;51(12):3492-8.

76. Han KA, Patel Y, Lteif AA, Chisholm R, Mather KJ. Contributions of dysglycaemia, obesity, and insulin resistance to impaired endothelium-dependent vasodilation in humans. Diabetes Metab Res Rev. 2011;27(4):354-61.

77. de Jongh RT, Serne EH, Ijzerman RG, Jorstad HT, Stehouwer CD. Impaired local microvascular vasodilatory effects of insulin and reduced skin microvascular vasomotion in obese women. Microvasc Res. 2008;75(2):256-62.

78. Ketel IJ, Serne EH, Ijzerman RG, Korsen TJ, Twisk JW, Hompes $\mathrm{PG}$, et al. Insulin-induced capillary recruitment is impaired in both lean and obese women with PCOS. Hum Reprod. 2011;26 (11):3130-7.

79. Ketel IJ, Stehouwer CD, Serne EH, Korsen TJ, Hompes PG, Smulders YM, et al. Obese but not normal-weight women with polycystic ovary syndrome are characterized by metabolic and microvascular insulin resistance. J Clin Endocrinol Metab. 2008;93(9):3365-72.

80. de Jongh RT, Serne EH, Ijzerman RG, de Vries G, Stehouwer CD. Free fatty acid levels modulate microvascular function: relevance for obesity-associated insulin resistance, hypertension, and microangiopathy. Diabetes. 2004;53(11):2873-82.

81. Brantsma AH, Bakker SJ, Hillege HL, de Zeeuw D, de Jong PE, Gansevoort RT. Urinary albumin excretion and its relation with $\mathrm{C}$-reactive protein and the metabolic syndrome in the prediction of type 2 diabetes. Diabetes Care. 2005;28:2525-30.

82. Friedman AN, Marrero D, Ma Y, Ackermann R, Narayan KM, Barrett-Connor E, et al. Value of urinary albumin-to-creatinine ratio as a predictor of type 2 diabetes in pre-diabetic individuals. Diabetes Care. 2008;31:2344-8.

83. Ikram MK, Janssen JA, Roos AM, Rietveld I, Witteman JC, Breteler MM, et al. Retinal vessel diameters and risk of impaired fasting glucose or diabetes: the Rotterdam study. Diabetes. 2006;55:506-10.

84. Kifley A, Wang JJ, Cugati S, Wong TY, Mitchell P. Retinal vascular caliber and the long-term risk of diabetes and impaired fasting glucose: the Blue Mountains Eye Study. Microcirculation. 2008;15:373-7.

85. Krakoff J, Funahashi T, Stehouwer CD, Schalkwijk CG, Tanaka $\mathrm{S}$, Matsuzawa $\mathrm{Y}$, et al. Inflammatory markers, adiponectin, and risk of type 2 diabetes in the Pima Indian. Diabetes Care. 2003;26:1745-51.
86. Meigs JB, O’Donnell CJ, Tofler GH, Benjamin EJ, Fox CS, Lipinska I, et al. Hemostatic markers of endothelial dysfunction and risk of incident type 2 diabetes: the Framingham offspring study. Diabetes. 2006;55:530-7.

87. Nguyen TT, Wang JJ, Islam FM, Mitchell P, Tapp RJ, Zimmet $\mathrm{PZ}$, et al. Retinal arteriolar narrowing predicts incidence of diabetes: the Australian Diabetes, Obesity and Lifestyle (AusDiab) study. Diabetes. 2008;57:536-9.

88. Perticone F, Maio R, Sciacqua A, Andreozzi F, Iemma G, Perticone M, et al. Endothelial dysfunction and c-reactive protein are risk factors for diabetes in essential hypertension. Diabetes. 2008;57:167-71.

89. Sattar N, Murray HM, Welsh P, Blauw GJ, Buckley BM, de Craen AJ, et al. Are elevated circulating intercellular adhesion molecule 1 levels more strongly predictive of diabetes than vascular risk? Outcome of a prospective study in the elderly. Diabetologia. 2009;52:235-9.

90. Song Y, Manson JE, Tinker L, Rifai N, Cook NR, Hu FB, et al. Circulating levels of endothelial adhesion molecules and risk of diabetes in an ethnically diverse cohort of women. Diabetes. 2007;56:1898-904.

91. Wang Z, Hoy WE. Albuminuria as a marker of the risk of developing type 2 diabetes in non-diabetic Aboriginal Australians. Int J Epidemiol. 2006;35:1331-5.

92. Wong TY, Klein R, Sharrett AR, Schmidt MI, Pankow JS, Couper DJ, et al. Retinal arteriolar narrowing and risk of diabetes mellitus in middle-aged persons. JAMA. 2002;287:2528-33.

93. Wong TY, Shankar A, Klein R, Klein BE, Hubbard LD. Retinal arteriolar narrowing, hypertension, and subsequent risk of diabetes mellitus. Arch Intern Med. 2005;165:1060-5.

94. Muris DM, Houben AJ, Schram MT, Stehouwer CD Microvascular dysfunction is associated with a higher incidence of type 2 diabetes mellitus: a systematic review and metaanalysis. Arterioscler Thromb Vasc Biol. 2012;32(12):3082-94.

95. To SS, Newman PM, Hyland VJ, Robinson BG, Schrieber L. Regulation of adhesion molecule expression by human synovial microvascular endothelial cells in vitro. Arthritis Rheum. 1996;39:467-77.

96. Kim F, Pham M, Maloney E, Rizzo NO, Morton GJ, Wisse BE, et al. Vascular inflammation, insulin resistance, and reduced nitric oxide production precede the onset of peripheral insulin resistance. Arterioscler Thromb Vasc Biol. 2008;28(11):1982-8.

97. Bonner, JS, Lantier L, Hasenour CM, James FD, Bracy DP, Wasserman DH (2012) Muscle-specific vascular endothelial growth factor deletion induces muscle capillary rarefaction creating muscle insulin resistance. Diabetes.

98. Chittari MV, McTernan P, Bawazeer N, Constantinides K, Ciotola $\mathrm{M}$, O'Hare JP, et al. Impact of acute hyperglycaemia on endothelial function and retinal vascular reactivity in patients with Type 2 diabetes. Diabet Med. 2011;28(4):450-4.

99. Giugliano D, Marfella R, Coppola L, Verrazzo G, Acampora R, Giunta R, et al. Vascular effects of acute hyperglycemia in humans are reversed by L-arginine. Evidence for reduced availability of nitric oxide during hyperglycemia. Circulation. 1997;95 (7):1783-90.

100. Watanabe K, Oba K, Suzuki T, Ouchi M, Suzuki K, Futami-Suda $\mathrm{S}$, et al. Oral glucose loading attenuates endothelial function in normal individual. Eur J Clin Invest. 2011;41(5):465-73.

101. Steinberg HO, Chaker H, Leaming R, Johnson A, Brechtel G, Baron AD. Obesity/Insulin resistance is associated with endothelial dysfunction. Implications for the syndrome of insulin resistance. J Clin Invest. 1996;47(2):310-3.

102. Costa RR, Villela NR, Souza MG, Boa BC, Cyrino FZ, Silva SV, et al. High fat diet induces central obesity, insulin resistance and microvascular dysfunction in hamsters. Microvasc Res. 2011;82 (3):416-22. 
103. de Jongh RT, Ijzerman RG, Serne EH, Voordouw JJ, Yudkin JS, de Waal HA, et al. Visceral and truncal subcutaneous adipose tissue are associated with impaired capillary recruitment in healthy individuals. J Clin Endocrinol Metab. 2006;91 (12):5100-6.

104. Jiang ZY, Lin YW, Clemont A, Feener EP, Hein KD, Igarashi M, et al. Characterization of selective resistance to insulin signaling in the vasculature of obese Zucker (fa/fa) rats. J Clin Invest. 1999;104(4):447-57.

105. Rizzo NO, Maloney E, Pham M, Luttrell I, Wessells H, Tateya S, et al. Reduced NO-cGMP signaling contributes to vascular inflammation and insulin resistance induced by high-fat feeding. Arterioscler Thromb Vasc Biol. 2010;30(4):758-65.

106. Tsuchiya K, Sakai H, Suzuki N, Iwashima F, Yoshimoto T, Shichiri M, et al. Chronic blockade of nitric oxide synthesis reduces adiposity and improves insulin resistance in high fatinduced obese mice. Endocrinology. 2007;148(10):4548-56.

107. Eringa EC, Stehouwer CD, Roos MH, Westerhof N, Sipkema P. Selective resistance to vasoactive effects of insulin in muscle resistance arteries of obese Zucker (fa/fa) rats. Am J Physiol Endocrinol Metab. 2007;293(5):E1134-9.

108. Arita Y, Kihara S, Ouchi N, Takahashi M, Maeda K, Miyagawa J, et al. Paradoxical decrease of an adipose-specific protein, adiponectin, in obesity. Biochem Biophys Res Commun. 1999;257(1):79-83.

109. Liu J, Jahn LA, Fowler DE, Barrett EJ, Cao W, Liu Z. Free fatty acids induce insulin resistance in both cardiac and skeletal muscle microvasculature in humans. J Clin Endocrinol Metab. 2011;96 (2):438-46.

110. Liu Z, Liu J, Jahn LA, Fowler DE, Barrett EJ. Infusing lipid raises plasma free fatty acids and induces insulin resistance in muscle microvasculature. J Clin Endocrinol Metab. 2009;94:3543-9.

111. Clerk LH, Rattigan S, Clark MG. Lipid infusion impairs physiologic insulin-mediated capillary recruitment and muscle glucose uptake in vivo. Diabetes. 2002;51(4):1138-45.

112. Watanabe S, Tagawa T, Yamakawa K, Shimabukuro M, Ueda S. Inhibition of the renin-angiotensin system prevents free fatty acid-induced acute endothelial dysfunction in humans. Arterioscler Thromb Vasc Biol. 2005;25(11):2376-80.

113. Chai W, Liu J, Jahn LA, Fowler DE, Barrett EJ, Liu Z. Salsalate attenuates free fatty acid-induced microvascular and metabolic insulin resistance in humans. Diabetes Care. 2011;34(7):1634-8.

114. Li H, Bao Y, Zhang X, Yu Y. Free fatty acids induce endothelial dysfunction and activate protein kinase $\mathrm{C}$ and nuclear factorkappaB pathway in rat aorta. Int J Cardiol. 2011;152(2):218-24.

115. Steinberg HO, Paradisi G, Hook G, Crowder K, Cronin J, Baron AD. Free fatty acid elevation impairs insulin-mediated vasodilation and nitric oxide production. Diabetes. 2000;49(7):1231-8.

116. Steinberg HO, Tarshoby M, Monestel R, Hook G, Cronin J, Johnson A, et al. Elevated circulating free fatty acid levels impair endothelium-dependent vasodilation. J Clin Invest. 1997;100 (5):1230-9.

117. Inyard AC, Chong DG, Klibanov AL, Barrett EJ. Muscle contraction, but not insulin, increases microvascular blood volume in the presence of free fatty acid-induced insulin resistance. Diabetes. 2009;58(11):2457-63.

118. Bakker W, Sipkema P, Stehouwer CD, Serne EH, Smulders YM, van Hinsbergh VW, et al. Protein kinase $\mathrm{C}$ theta activation induces insulin-mediated constriction of muscle resistance arteries. Diabetes. 2008;57(3):706-13.

119. Youd JM, Rattigan S, Clark MG. Acute impairment of insulinmediated capillary recruitment and glucose uptake in rat skeletal muscle in vivo by TNF-alpha. Diabetes. 2000;49(11):1904-9.

120. Zhang L, Wheatley CM, Richards SM, Barrett EJ, Clark MG, Rattigan S. TNF-alpha acutely inhibits vascular effects of physiological but not high insulin or contraction. Am J Physiol Endocrinol Metab. 2003;285(3):E654-60.
121. Eringa EC, Stehouwer CD, Walburg K, Clark AD, van Nieuw Amerongen GP, Westerhof $\mathrm{N}$, et al. Physiological concentrations of insulin induce endothelin-dependent vasoconstriction of skeletal muscle resistance arteries in the presence of tumor necrosis factor-alpha dependence on c-Jun Nterminal kinase. Arterioscler Thromb Vasc Biol. 2006;26 (2):274-80

122. Hirosumi J, Tuncman G, Chang L, Gorgun CZ, Uysal KT, Maeda $\mathrm{K}$, et al. A central role for JNK in obesity and insulin resistance. Nature. 2002;420(6913):333-6.

123. Li G, Barrett EJ, Barrett MO, Cao W, Liu Z. Tumor necrosis factor-alpha induces insulin resistance in endothelial cells via a p38 mitogen-activated protein kinase-dependent pathway. Endocrinology. 2007;148(7):3356-63.

124. Meijer RI, Bakker W, Alta CL, Sipkema P, Yudkin JS, Viollet B, et al. (2012). Perivascular adipose tissue control of insulininduced vasoreactivity in muscle is impaired in $\mathrm{db} / \mathrm{db}$ Mice. Diabetes.

125. Koenig W, Khuseyinova N, Baumert J, Meisinger C, Lowel H. Serum concentrations of adiponectin and risk of type 2 diabetes mellitus and coronary heart disease in apparently healthy middleaged men: results from the 18-year follow-up of a large cohort from southern Germany. J Am Coll Cardiol. 2006;48(7):1369-77.

126. Chen H, Montagnani M, Funahashi T, Shimomura I, Quon MJ. Adiponectin stimulates production of nitric oxide in vascular endothelial cells. J Biol Chem. 2003;278(45):45021-6.

127. Zheng Q, Yuan Y, Yi W, Lau WB, Wang Y, Wang X, et al. C1q/ TNF-related proteins, a family of novel adipokines, induce vascular relaxation through the adiponectin receptor-1/AMPK/ eNOS/nitric oxide signaling pathway. Arterioscler Thromb Vasc Biol. 2011;31(11):2616-23.

128. Luo N, Liu J, Chung BH, Yang Q, Klein RL, Garvey WT, et al. Macrophage adiponectin expression improves insulin sensitivity and protects against inflammation and atherosclerosis. Diabetes. 2010;59(4):791-9.

129. Meijer RI, Serne EH, Smulders YM, van Hinsbergh VW, Yudkin JS, Eringa EC. Perivascular adipose tissue and its role in type 2 diabetes and cardiovascular disease. Curr Diab Rep. 2011;11 (3):211-7.

130. Tilg H, Moschen AR. Adipocytokines: mediators linking adipose tissue, inflammation and immunity. Nat Rev Immunol. 2006;6 (10):772-83.

131. Karlsson C, Lindell K, Ottosson M, Sjostrom L, Carlsson B, Carlsson LM. Human adipose tissue expresses angiotensinogen and enzymes required for its conversion to angiotensin II. J Clin Endocrinol Metab. 1998;83(11):3925-9.

132. Schling P, Mallow H, Trindl A, Loffler G. Evidence for a local renin angiotensin system in primary cultured human preadipocytes. Int J Obes Relat Metab Disord. 1999;23(4):336-41.

133. Rahmouni K, Mark AL, Haynes WG, Sigmund CD. Adipose depot-specific modulation of angiotensinogen gene expression in diet-induced obesity. Am J Physiol Endocrinol Metab. 2004;286(6):E891-5.

134. Andreozzi F, Laratta E, Sciacqua A, Perticone F, Sesti G. Angiotensin II impairs the insulin signaling pathway promoting production of nitric oxide by inducing phosphorylation of insulin receptor substrate-1 on Ser312 and Ser616 in human umbilical vein endothelial cells. Circ Res. 2004;94(9):1211-8.

135. Velloso LA, Folli F, Sun XJ, White MF, Saad MJ, Kahn CR. Cross-talk between the insulin and angiotensin signaling systems. Proc Natl Acad Sci U S A. 1996;93(22):12490-5.

136. Rajagopalan S, Kurz S, Munzel T, Tarpey M, Freeman BA, Griendling KK, et al. Angiotensin II-mediated hypertension in the rat increases vascular superoxide production via membrane NADH/NADPH oxidase activation. Contribution to alterations of vasomotor tone. J Clin Invest. 1996;97(8):1916-23. 
137. Zhou MS, Schulman IH, Raij L. Role of angiotensin II and oxidative stress in vascular insulin resistance linked to hypertension. Am J Physiol Heart Circ Physiol. 2009;296(3):H833-9.

138. Hong HJ, Chan P, Liu JC, Juan SH, Huang MT, Lin JG, et al. Angiotensin II induces endothelin-1 gene expression via extracellular signal-regulated kinase pathway in rat aortic smooth muscle cells. Cardiovasc Res. 2004;61(1):159-68.

139. Imai T, Hirata Y, Emori T, Yanagisawa M, Masaki T, Marumo F. Induction of endothelin-1 gene by angiotensin and vasopressin in endothelial cells. Hypertension. 1992;19(6 Pt 2):753-7.
140. Bakker W, Eringa EC, Sipkema P, van Hinsbergh VW. Endothelial dysfunction and diabetes: roles of hyperglycemia, impaired insulin signaling and obesity. Cell Tissue Res. 2009;335(1):165-89.

141. Eringa EC, Bakker W, van Hinsbergh VW. Paracrine regulation of vascular tone, inflammation and insulin sensitivity by perivascular adipose tissue. Vascul Pharmacol. 2012;56(5-6):204-9.

142. Yudkin JS, Eringa E, Stehouwer CD. "Vasocrine" signalling from perivascular fat: a mechanism linking insulin resistance to vascular disease. Lancet. 2005;365(9473):1817-20. 